\title{
MOLECULAR INTERACTION OF CHILI COMPOUNDS (Capsicum annum L) AS A COX-2 INHIBITOR
}

\author{
Yohanes Bare*, Nurul Imaniyah Ahmad, Yohanes Nong Bunga \\ Program Studi Pendidikan Biologi, Fakultas Keguruan dan Ilmu Pendidikan, Universitas Nusa \\ Nipa Indonesia, Jl. Kesehatan No 03, Kelurahan Beru, Maumere, Prov. NTT, Indonesia \\ "bareyohanes@gmail.com
}

Doi: https://doi.org/10.31943/mangiferaedu.v6i2.124

Received: October 05, $2021 \quad$ Accepted: January 15, 2022 Published: January 31, 2022

Citation: Ahmad, N. I., Bunga, Y. N., \& Bare, Y. (2022). Molekular Interaction of Chili Compounds (Capsicum annum L) as a COX-2 Inhibitor. Jurnal Mangifera Edu, 6(2), 115-128.

\section{ABSTRACT}

Curly red chili (Capsicum annum L.) is a vegetable that has health benefits. Besides being used as an addictive substance in traditional medicine, Capsicum annum L. is also used for cough treatment, antiseptic, anti-irritant, anti-inflammatory. This research study aims to analyze the physicochemical and its molecular interactions with COX-2. Capsaicin (CID: 1548943), dihydrocapsaicin (CID: 107982), and homocapsaicin (CID: 6442566) compounds were downloaded from PubChem. While the COX protein (ID: 6cox) from the Protein Data Bank. Molecular interaction and analized by HEX. 8.0.0 and Discovery Studio. The three compounds contained in curly red chilies have unique physicochemical characteristics. The results of the interaction show that the curly mera chili has a physiological function by inhibiting the performance of COX-2.

$x$-2, in-silico, red chili, physicochemical

\begin{abstract}
ABSTRAK
Cabai merah keriting (Capsicum annum L.) termasuk dalam sayuran memiliki manfaat dibidang kesehatan. Selain pemanfaatan sebagai zat aditif dalam pengobatan tradisional Capsicum annum L. juga digunakan untuk pengobatan batuk, antiseptkc, kontra iritasi, anti inflamasi. Kajian penelitian ini bertujuan menganalisis fisikokimia serta interaksi molekulernya terhadap COX-2. Senyawa capsaicin (CID: 1548943), dihydrocapsaicin (CID: 107982) dan homocapsaicin (CID: 6442566) diunduh dari pubchem.com. Sedangkan protein COX (ID: 6cox) dari Protein Data Bank. Interaksi molekuler senyawa dan protein COX-2 menggunakan perangkat lunak HEX. 8.0.0 dan hasil dianalis dan divisualisasi menggunakan perangkat lunak Discovery Studio. Ketiga senyawa yang terkandung dalam cabai merah keriting memiliki karakteristik fisikokimia yang unik. Hasil interaksi molekuler menunjukan bahwa senyawa cabai merah keriting memiliki fungsi fisiologi dengan menghambat kinerja COX-2. Penghamatan yang dilakukan oleh senyawa yang terkandung dalam cabai merah berpotensi sebagai anti inflamasi
\end{abstract}

Kata Kunci: cabai merah keriting, cox-2, fisikoimia, in-silico 
Jurnal Mangifera Edu, Volume 6, Issue 2, January 2022, 115-128

\section{PENDAHULUAN}

Cabai merah keriting (Capsicum annum L.) salah satu sayuran yang dibudidayakan oleh petani di Indonesia (Sukmawati, 2015). Fungsi cabai merah keriting mengalami perubahan dari bumbu dapur menjadi bahan baku dalam obat-obatan (Fitriani dkk., 2013). Studi literatur menunjukkan tanaman cabai mengandung berbagai macam bioaktif kimia. Studi literatur tanaman cabai menunjukkan kandungan utama Capsaicinoid pada cabai adalah capsaicin, diikuti oleh dihydrocapsaicin, dan homocapsaicin obat-obatan (Izzati, 2018). Jenis sakit yang diobati menurut kajian referensi merupakan kondisi inflamasi didalam tubuh manusia (Bare et al., 2018, 2019; Bhadoriya, 2012). Kandungan cabai (Capsicum annuum L), mengandung senyawa yang memiliki fungsi sebagai antibakteri (Agarwal et al., 2017; Marini et al., 2015), antioksidan (Arumingtyas et al., 2018; Dima, et al., 2013), anti-inflamasi (Jolayemi \& Ojewole, 2013), dan anti virus (Marini et al., 2015). Kandungan cabai di Indonesia beberapa sudah diidentifikasi memiliki berbagai macam variasi dan memiliki perbedaan terhadap kandungan capsaicinoid (Arumingtyas et al., 2017, 2018; Kusnadi et al., 2019; Musfiroh et al., 2013).

Pada saat terjadi infeksi tubuh akan merespon inflamasi. Proses inflamasi yang terjadi dalam tubuh dapat menyebabkan perubahan fungsi fisiologis tubuh manusia (Bare et al., 2018; Jolayemi \& Ojewole, 2013). Pencegahan inflamasi yang berlebihan dilakukan dengan menghentikan kinerja COX-2 yang memiliki tugas sebagai stimulator inflamasi dalam keadaan peradangan. Stimulasi COX-2 mengaktifkan prostaglandin G2 menjadi prostaglandin $\mathrm{H} 2$ yang meningkatkan inflamasi dalam tubuh (Abdulkhaleq et al., 2018; Kellogg, Cheng, et al., 2008). Proses penghambatan inflamasi dapat dilakukan dengan menghambat kinerja COX-2. Proses penurunan dapat dilakukan dengan mencari sumber daya alam bioaktif yang memiliki sifat medis yang dapat diperoleh dari tanaman berupa metabolit sekundernya (Phan et al., 2018). Tujuan penelitian ini adalah menganalisis potensi senyawa tanaman cabai terhadap COX-2.

\section{METODOLOGI PENELITIAN}

\section{Preparasi Ligan dan Protein}

Kegiatan penelitian ini diawali dengan pengambilan Protein COX-2 dengan nomor ID: 6cox yang diunduh dari Protein Data Bank (PDB), sedangkan Senyawa capsaicin (CID: 1548943), dihydrocapsaicin (CID: 107982) dan homocapsaicin (CID: 6442566) diperoleh dari PubChem.com. Proses minimalisir energi dan menghilangkan ligan dan molekuler di adaptasi dari Penelitian (Bare \& Sari, 2021). 
Jurnal Mangifera Edu, Volume 6, Issue 2, January 2022, 115-128

\section{Molecular Docking}

Interaksi Molekuler senyawa dalam cabai merah kriting dan protein COX-2 menggunakan perangkat lunak HEX 8.0.0. Analisis menggunakan perangkat lunak Discovery Studio Client 4.1. Kajian dalam interaksi ini meliputi residu asam amino yang berikatan dengan senyawa cabai merah keriting, jenis ikatan yang terbentuk serta energi ikatan yang mengikat protein dan ligan (Bare \& Sari, 2021).

\section{HASIL DAN PEMBAHASAN}

\section{Sifat fisikokimia Capsaicin, Dihydrocapsaicin, Homocapsaicin}

Capsaicin tergolong alkaloid yang di isolasi dari cabai merah keriting (Capsicum annum L.). Capsaicin terletak terletak pada bagian buah Capsicum annum L. terutama pada plasenta (Purwanto, 2017). Dihydrocapsaicin adalah capsaicinoid dan analog serta penghasil capsicin pada cabai memiliki sifat mengiritasi dengan total kandungan $22 \%$ dengan tingkat pedas yang tinggi (Izzati, 2018). Homocapsaicin adalah capsaicinoid dan analog serta penghasil capsaicini pada cabai (Capsicum). Homocapsaicin menyumbang sekitar $1 \%$ dari total campuran capsaicinoids memiliki sekitar setengah kepedasan capsaicin. Homocapsaicin murni adalah senyawa lipofolik yang tidak berbau. Pada skala Scoville, homocapsaicin memiliki 850.000 SHU (Scoville Heat Units) (Izzati, 2018). Homocapsaicin yang dikonsumsi manusia sangat tinggi tersedia secara hayati pada manusia.

Tabel 1. Sifat Fisikokimia Tanaman Cabai Merah Keriting (Capsicum annum L)

\begin{tabular}{lllll}
\hline No & \multicolumn{1}{c}{ ID } & \multicolumn{1}{c}{ Capsaicin } & \multicolumn{1}{c}{$\begin{array}{c}\text { Senyawa } \\
\text { Dihydrocapsaicin }\end{array}$} & \multicolumn{1}{c}{ Homocapsaicin } \\
\hline 1. & PubChem ID & 1548943 & 107982 & 6442566 \\
2. & Formula & $\underline{\mathrm{C}}_{18} \underline{\mathrm{H}}_{27} \underline{\mathrm{NO}}_{3}$ & $\underline{\mathrm{C}}_{18} \underline{\mathrm{H}}_{29} \underline{\mathrm{NO}}_{3}$ & $\underline{\mathrm{C}}_{19} \underline{\mathrm{H}}_{29} \underline{\mathrm{NO}}_{3}$ \\
3. & Molweight & $305.412 \mathrm{~g} / \mathrm{mol}$ & $307.428 \mathrm{~g} / \mathrm{mol}$ & $319.438 \mathrm{~g} / \mathrm{mol}$ \\
4. & LogP & 4.180 & 4.405 & 4.571 \\
5. & Heavy Atoms & 22 & 22 & 23 \\
6. & Rotatable Bonds & 9 & 10 & 10 \\
7. & HBD & 2 & 2 & 2 \\
8. & HBA & 3 & 3 & 3 \\
9. & Polar Surface Area & $58.560 \AA^{2}$ & $58.560 \AA^{2}$ & $58.560 \AA^{2}$ \\
\hline
\end{tabular}

Berdasarkan data Tabel 1. dapat disimpulkan bahwa Kandungan fisikokimia senyawa capsaicin, Dihydrocapsaicin dan Homocapsaicin berpotensi sebagai senyawa yang 
Jurnal Mangifera Edu, Volume 6, Issue 2, January 2022, 115-128

dapat diserap dengan mudah oleh membran sel serta memiliki potensi permebilitas yang tinggi (Lipinski, 2004; Lipinski dkk, 2001).

\section{Interaksi Molekuler Senyawa Capsaicin Terhadap COX-2}

Senyawa capsaicin diinteraksikan dengan protein COX-2 menunjukan beberapa ikatan residu asam amino pada senyawa capsaicin yaitu asam amino LEU145 dan LEU224 yang bersifat Pi-Alkyl, residu asam amino GLU236, SER143, dan TRP139 menunjukkan ikatan hydrogen, gaya Van der Waals pada residu GLY225, LEU145, ASN231, ASP223, GLY235, THR237, LEU238, PHE142, ASN144, dan SER146. Sedangkan residu asam amino LEU224 membentuk unfavorable bump (Gambar 1b).

a.

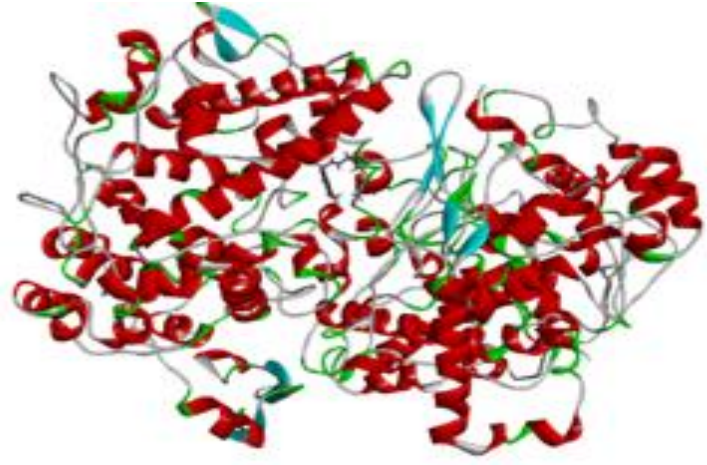

b.

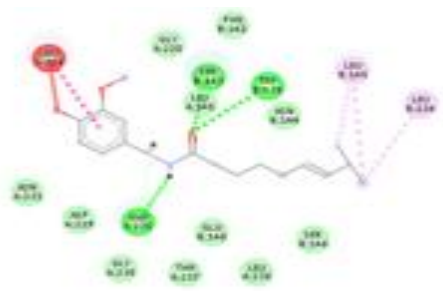

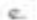
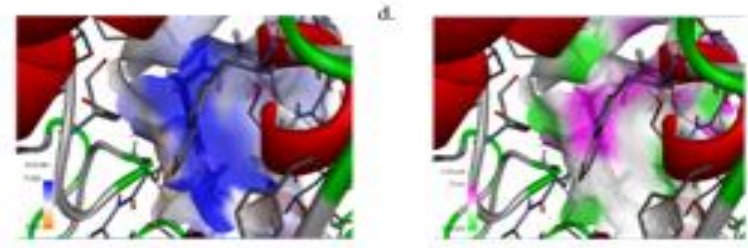

f.
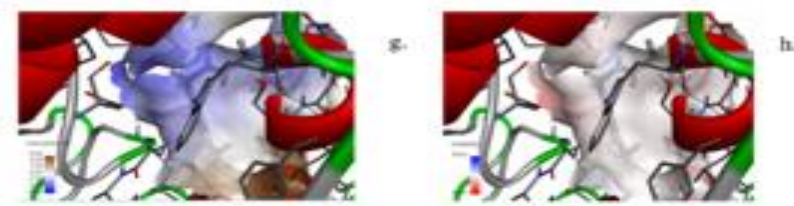
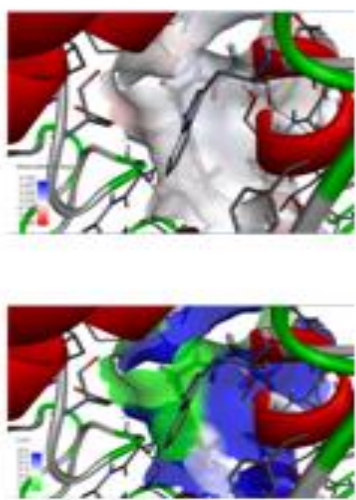

Gambar 1. Interaksi Senyawa Capsaicin dan COX-2 a. Struktur 3D, b. Struktur 2D, c. aromatic, d. H-Bond, e. Charge, f. Hydrophobic, g. Ionizability, h. SAS)

Interaksi antara COX-2 dengan capsaicin menunjukkan nilai aromatik memiliki satu cincin aromatic (Gambar 1c) yang memiliki fungsi sebagai donor dan acceptor terhadap COX-2 diindikasikan dengan warna biru pada permukaan sebagai indikasi acceptor dan warna pink keunguan sebagai donor (Gambar 1d). Senyawa capsaicin cenderung bersifat netral sehingga ligan bermuatan 0 (Gambar 1e dan Gambar 1g). Interaksi antara COX-2 dengan capsaicin memiliki tingkat hidrofobisitas yang rendah (Gambar 1f). 
Jurnal Mangifera Edu, Volume 6, Issue 2, January 2022, 115-128

Tabel 2. Interaki Senyawa Capsaicin dan COX-2

\begin{tabular}{|c|c|c|c|c|c|c|c|}
\hline Complexes & $\begin{array}{c}\text { Energy } \\
\text { (Kal/ } \\
\text { Mol) }\end{array}$ & Name & Distance & Category & Types & $\begin{array}{c}\text { From } \\
\text { Chemistry }\end{array}$ & $\begin{array}{c}\text { From } \\
\text { Chemistry }\end{array}$ \\
\hline \multirow{17}{*}{$\begin{array}{l}\text { Capsaicin- } \\
\text { COX2 }\end{array}$} & -261.55 & A:GLY225:CA - & 3.64722 & Hydrogen & Carbon & H-Donor & $\mathrm{H}-$ \\
\hline & & A:ASP229:OD2 & & Bond & $\begin{array}{l}\text { Hydrogen } \\
\text { Bond }\end{array}$ & & Acceptor \\
\hline & & $\begin{array}{l}\text { A:LEU145 - } \\
\text { A:LEU224 }\end{array}$ & 5.27668 & Hydrophobic & Alkyl & Alkyl & Alkyl \\
\hline & & A:LYS211:HZ2 - & 2.01271 & Hydrogen & Conventional & H-Donor & $\mathrm{H}-$ \\
\hline & & A:ASN231:OD1 & & Bond & $\begin{array}{l}\text { Hydrogen } \\
\text { Bond }\end{array}$ & & Acceptor \\
\hline & & $\begin{array}{l}\text { A:GLY235:H - } \\
\text { A:ASN231:O }\end{array}$ & 1.92447 & $\begin{array}{l}\text { Hydrogen } \\
\text { Bond }\end{array}$ & $\begin{array}{l}\text { Conventional } \\
\text { Hydrogen } \\
\text { Bond }\end{array}$ & H-Donor & $\begin{array}{l}\mathrm{H}- \\
\text { Acceptor }\end{array}$ \\
\hline & & $\begin{array}{l}\text { A:ARG240:H - } \\
\text { A:THR237:O }\end{array}$ & 2.72664 & $\begin{array}{l}\text { Hydrogen } \\
\text { Bond }\end{array}$ & $\begin{array}{l}\text { Conventional } \\
\text { Hydrogen } \\
\text { Bond }\end{array}$ & H-Donor & $\begin{array}{l}\mathrm{H}- \\
\text { Acceptor }\end{array}$ \\
\hline & & $\begin{array}{l}\text { A:HIS242:H - } \\
\text { A:LEU238:O }\end{array}$ & 1.90949 & $\begin{array}{l}\text { Hydrogen } \\
\text { Bond }\end{array}$ & $\begin{array}{l}\text { Conventional } \\
\text { Hydrogen } \\
\text { Bond }\end{array}$ & H-Donor & $\begin{array}{l}\mathrm{H}- \\
\text { Acceptor }\end{array}$ \\
\hline & & $\begin{array}{l}\text { B:PHE142:H - } \\
\text { B:SER138:O }\end{array}$ & 2.78464 & $\begin{array}{l}\text { Hydrogen } \\
\text { Bond }\end{array}$ & $\begin{array}{l}\text { Conventional } \\
\text { Hydrogen } \\
\text { Bond }\end{array}$ & H-Donor & $\begin{array}{l}\text { H- } \\
\text { Acceptor }\end{array}$ \\
\hline & & $\begin{array}{l}\text { B:ASN144:H - } \\
\text { B:GLU140:O }\end{array}$ & 2.06377 & $\begin{array}{l}\text { Hydrogen } \\
\text { Bond }\end{array}$ & $\begin{array}{l}\text { Conventional } \\
\text { Hydrogen } \\
\text { Bond }\end{array}$ & H-Donor & $\begin{array}{l}\mathrm{H}- \\
\text { Acceptor }\end{array}$ \\
\hline & & $\begin{array}{l}\text { B:SER146:H - } \\
\text { B:ASN144:OD1 }\end{array}$ & 2.1082 & $\begin{array}{l}\text { Hydrogen } \\
\text { Bond }\end{array}$ & $\begin{array}{l}\text { Conventional } \\
\text { Hydrogen } \\
\text { Bond }\end{array}$ & H-Donor & $\begin{array}{l}\text { H- } \\
\text { Acceptor }\end{array}$ \\
\hline & & $\begin{array}{l}\text { A:GLU236:H - } \\
\text { A:GLU236:OE1 }\end{array}$ & 1.97436 & $\begin{array}{l}\text { Hydrogen } \\
\text { Bond }\end{array}$ & $\begin{array}{l}\text { Conventional } \\
\text { Hydrogen } \\
\text { Bond }\end{array}$ & H-Donor & $\begin{array}{l}\text { H- } \\
\text { Acceptor }\end{array}$ \\
\hline & & $\begin{array}{l}\text { B:LEU145:H - } \\
\text { B:SER143:O }\end{array}$ & 2.86998 & $\begin{array}{l}\text { Hydrogen } \\
\text { Bond }\end{array}$ & $\begin{array}{l}\text { Conventional } \\
\text { Hydrogen } \\
\text { Bond }\end{array}$ & H-Donor & $\begin{array}{l}\text { H- } \\
\text { Acceptor }\end{array}$ \\
\hline & & $\begin{array}{l}\text { B:PHE142:H - } \\
\text { B:TRP139:O }\end{array}$ & 2.57183 & $\begin{array}{l}\text { Hydrogen } \\
\text { Bond }\end{array}$ & $\begin{array}{l}\text { Conventional } \\
\text { Hydrogen } \\
\text { Bond }\end{array}$ & H-Donor & $\begin{array}{l}\text { H- } \\
\text { Acceptor }\end{array}$ \\
\hline & & $\begin{array}{l}\text { B:LEU145:H - } \\
\text { B:SER143:O }\end{array}$ & 2.86998 & $\begin{array}{l}\text { Hydrogen } \\
\text { Bond }\end{array}$ & $\begin{array}{l}\text { Conventional } \\
\text { Hydrogen } \\
\text { Bond }\end{array}$ & H-Donor & $\begin{array}{l}\mathrm{H}- \\
\text { Acceptor }\end{array}$ \\
\hline & & $\begin{array}{l}\text { B:LEU224:H - } \\
\text { B:ARG222:O }\end{array}$ & 2.59877 & $\begin{array}{l}\text { Hydrogen } \\
\text { Bond }\end{array}$ & $\begin{array}{l}\text { Conventional } \\
\text { Hydrogen } \\
\text { Bond }\end{array}$ & H-Donor & $\begin{array}{l}\text { H- } \\
\text { Acceptor }\end{array}$ \\
\hline & & $\begin{array}{l}\text { A:LEU224:CB - } \\
\text { :LIG1:O }\end{array}$ & 2.15741 & Unfavorable & $\begin{array}{l}\text { Unfavorable } \\
\text { Bump }\end{array}$ & & Steric \\
\hline
\end{tabular}

Nilai Solvent Accessible Surfance (SAS) pada permukaan capsaicin cukup tinggi (Gambar 1h). Tampilan interaksi ini memberikan informasi bahwa ikatan antar ligan dan protein memiliki nilai interaksi yang sangat tinggi terhadap pengikatan sisi aktif dari protein COX-2 (Bare et al., 2019; Santoso \& Atmajaya, 2016).

Interaksi molekuler antara COX-2 terhadap capsaicin memberikan efek terhadap sel target karena mengikat pada sisi aktif COX-2. Capsaicin mengikat 15 residu asam amino 
Jurnal Mangifera Edu, Volume 6, Issue 2, January 2022, 115-128

sehingga berpengaruh terhadap sisi aktinya dan memiliki fungsi menghambat kinerjanya. Beberapa target terdampak terhadap ikatan tersebut yaitu pengaruh terhadap produksi COX2 yaitu endotel pada jaringan vascular (Bare et al., 2019). Pada tabel 2 terdapat residu asam amino LEU224 membentuk ikatan elektrostatik. Interaksi antara protein dan ligan ditemukan beberapa ikatan hydrogen pada residu GLU236, SER143, dan TRP139 kehadiran ikatan hydrogen pada ikatan yang terbentuk akan meningkatkan dan menguatkan ikatan. Selain itu ikatan hydrogen juga meningkatkan afinitas dan stabilitas interaksi protein dan ligan (Bare, 2021).

\section{Interaksi Molekuler Senyawa Dihydrocapsaicin Terhadap COX-2}

Interaksi molekuelr senyawa dihydrocapsaicin terhadap COX-2 merilis beberapa residu asam amino LEU152 bersifat Pi-Sigma. Residu asam amino PRO154 dan ALA156 menunjukkan alkyl. Residu asam amino ASN34, ASN39, PRO40, CYS41, ARG44, GLY45, GLU47, CYS47, TYR130, HIS133, TYR134, TYR135, GLY135, VAL155, ASP157, GLN461, GLU465, dan ARG469 membentuk gaya van der waals (Gambar 2b).

a.
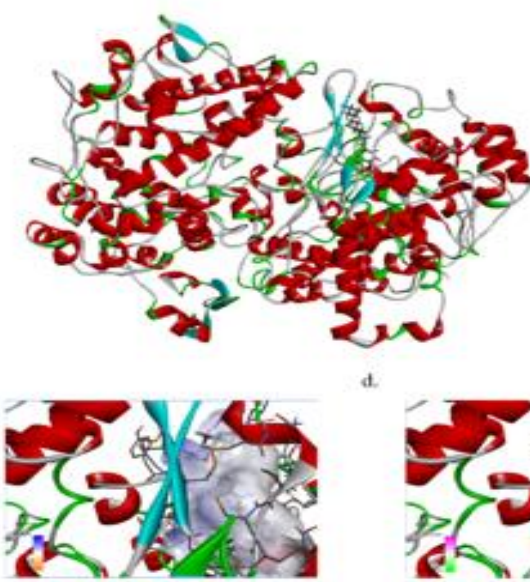

d.
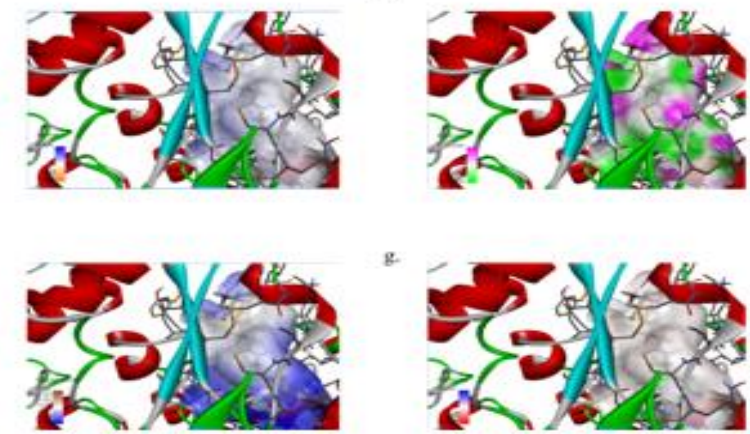

b.

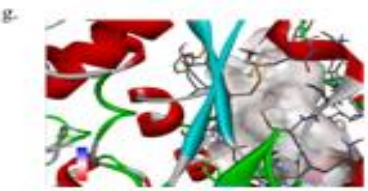

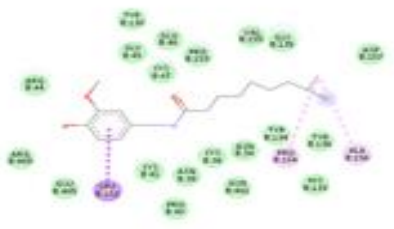
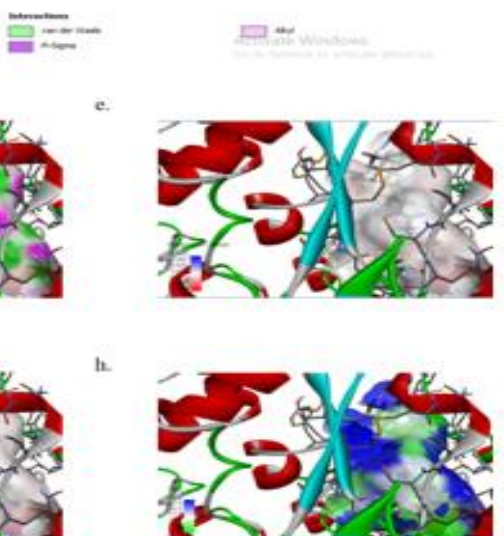

Gambar 2. Interaksi Senyawa Diydrocapsaicin dan COX-2 a. Struktur 3D, b. Struktur 2D, c. Aromatic, d. H-Bond, e. Charge, f. Hydrophobic, g. Ionizability, h. SAS)

Interaksi antara COX-2 dengan dihydrocapsaicin menunjukkan nilai aromatic pada senyawa dihydrocapsaicin cenderung di satu tempat (Gambar 2c). Senyawa dihydrocapsaicin juga berfungsi sebagai donor dan acceptor terhadap (Gambar 2d). 
Jurnal Mangifera Edu, Volume 6, Issue 2, January 2022, 115-128

Senyawa dihydrocapsaicin cenderung bersifat netral sehingga ligan bermuatan 0 (Gambar 2e dan Gambar 2g). Interaksi antara COX-2 dengan dihydrocapsaicin menunjukkan tingkat hidrofobisitas yang rendah (Gambar 2f). Nilai Solvent Accessible Surfance (SAS) pada permukaan dihydrocapsaicin cukup tinggi (Gambar $2 \mathrm{~h}$ ). Tampilan interaksi ini memberikan informasi bahwa ikatan antar ligan dan protein memiliki nilai interaksi yang sangat tinggi terhadap pengikatan sisi aktif dari protein COX-2 (Bare dkk., 2019; Santoso \& Atmajaya, 2016).

Energi yang terbentuk dari ikatan-ikatan yang terbentuk antara ligan dan protein adalah $-388.75 \mathrm{cal} / \mathrm{mol}$. Dihydrocapsaicin berpotensi sebagai inhibitor COX-2 dengan menstimulus penghambatan pada lima residu asam amino COX-2. Dihidrocapsaicin berpotensi sebagai inhibitor COX-2 menghambat kinerja sitokim pro inflamasi sebagai akibat dari diinduksi COX-2 (Bayala et al., 2020; Funk et al., 2016). Pada Tabel 3 terdapat residu asam amino LEU152 membentuk ikatan elektrostatik. Interaksi yang terbentuk antara keempat senyawa Dihydrocapsaicin berkontribusi terhadap kuat-lemahnya ikatan yang diindikasikan oleh afinitas ikatan, selain itu tinggi rendahnya hidrofobisitas, peranan donor/acceptor pada ligand-protein (Chen et al., 2016). 
Jurnal Mangifera Edu, Volume 6, Issue 2, January 2022, 115-128

Tabel 3. Interaksi Senyawa Dihydrocapsaicin-COX-2

\begin{tabular}{|c|c|c|c|c|c|c|c|}
\hline $\begin{array}{c}\text { Complexe } \\
\text { s }\end{array}$ & $\begin{array}{c}\text { Energy } \\
\text { (Kal/M } \\
\text { ol) } \\
\end{array}$ & Name & Distance & Category & Types & $\begin{array}{c}\text { From } \\
\text { Chemistry }\end{array}$ & $\begin{array}{c}\text { From } \\
\text { Chemistry }\end{array}$ \\
\hline \multirow[t]{14}{*}{$\begin{array}{l}\text { Dihydroca } \\
\text { psaicin- } \\
\text { COX2 }\end{array}$} & \multirow[t]{14}{*}{-388.75} & $\begin{array}{l}\text { B:ARG44: } \\
\text { HH11 - } \\
\text { B:ASP125 } \\
\text { :OD1 }\end{array}$ & 2.6629 & $\begin{array}{l}\text { Hydrogen } \\
\text { Bond;Electr } \\
\text { ostatic }\end{array}$ & $\begin{array}{l}\text { Salt } \\
\text { Bridge;Att } \\
\text { ractive } \\
\text { Charge }\end{array}$ & $\begin{array}{l}\mathrm{H}- \\
\text { Donor;Posi } \\
\text { tive }\end{array}$ & $\begin{array}{l}\text { H- } \\
\text { Acceptor;N } \\
\text { egative }\end{array}$ \\
\hline & & $\begin{array}{l}\text { B:GLY45: } \\
\text { H - } \\
\text { B:GLN42: } \\
\text { O }\end{array}$ & 2.05126 & $\begin{array}{l}\text { Hydrogen } \\
\text { Bond }\end{array}$ & $\begin{array}{l}\text { Conventio } \\
\text { nal } \\
\text { Hydrogen } \\
\text { Bond }\end{array}$ & H-Donor & H-Acceptor \\
\hline & & $\begin{array}{l}\text { B:GLU46: } \\
\text { H - } \\
\text { B:ASP58: } \\
\text { O }\end{array}$ & 2.2403 & $\begin{array}{l}\text { Hydrogen } \\
\text { Bond }\end{array}$ & $\begin{array}{l}\text { Conventio } \\
\text { nal } \\
\text { Hydrogen } \\
\text { Bond }\end{array}$ & H-Donor & H-Acceptor \\
\hline & & $\begin{array}{l}\text { B:ASN39: } \\
\text { H - } \\
\text { B:CYS36: } \\
\text { O }\end{array}$ & 1.97247 & $\begin{array}{l}\text { Hydrogen } \\
\text { Bond }\end{array}$ & $\begin{array}{l}\text { Conventio } \\
\text { nal } \\
\text { Hydrogen } \\
\text { Bond }\end{array}$ & H-Donor & H-Acceptor \\
\hline & & $\begin{array}{l}\text { B:ASN34: } \\
\text { H - } \\
\text { B:ASP158 } \\
\text { :OD2 }\end{array}$ & 2.07366 & $\begin{array}{l}\text { Hydrogen } \\
\text { Bond }\end{array}$ & $\begin{array}{l}\text { Conventio } \\
\text { nal } \\
\text { Hydrogen } \\
\text { Bond }\end{array}$ & H-Donor & H-Acceptor \\
\hline & & $\begin{array}{l}\text { B:HIS133: } \\
\text { H - } \\
\text { B:ASN13 } \\
\text { 1:OD1 }\end{array}$ & 1.96674 & $\begin{array}{l}\text { Hydrogen } \\
\text { Bond }\end{array}$ & $\begin{array}{l}\text { Conventio } \\
\text { nal } \\
\text { Hydrogen } \\
\text { Bond }\end{array}$ & H-Donor & H-Acceptor \\
\hline & & $\begin{array}{l}\text { B:GLN42: } \\
\text { H - } \\
\text { B:PRO40: } \\
\text { O }\end{array}$ & 3.03647 & $\begin{array}{l}\text { Hydrogen } \\
\text { Bond }\end{array}$ & $\begin{array}{l}\text { Conventio } \\
\text { nal } \\
\text { Hydrogen } \\
\text { Bond }\end{array}$ & H-Donor & H-Acceptor \\
\hline & & $\begin{array}{l}\text { B:TYR13 } \\
4: H- \\
\text { B:ASN13 } \\
1: O\end{array}$ & 1.82489 & $\begin{array}{l}\text { Hydrogen } \\
\text { Bond }\end{array}$ & $\begin{array}{l}\text { Conventio } \\
\text { nal } \\
\text { Hydrogen } \\
\text { Bond }\end{array}$ & H-Donor & H-Acceptor \\
\hline & & $\begin{array}{l}\text { B:ASP157 } \\
: \text { H - } \\
\text { B:ASP157 } \\
\text { :OD1 }\end{array}$ & 2.37262 & $\begin{array}{l}\text { Hydrogen } \\
\text { Bond }\end{array}$ & $\begin{array}{l}\text { Conventio } \\
\text { nal } \\
\text { Hydrogen } \\
\text { Bond }\end{array}$ & H-Donor & H-Acceptor \\
\hline & & $\begin{array}{l}\text { B:GLN46 } \\
\text { 1:HE21 - } \\
\text { B:PRO15 } \\
3: O\end{array}$ & 2.16612 & $\begin{array}{l}\text { Hydrogen } \\
\text { Bond }\end{array}$ & $\begin{array}{l}\text { Conventio } \\
\text { nal } \\
\text { Hydrogen } \\
\text { Bond }\end{array}$ & H-Donor & H-Acceptor \\
\hline & & $\begin{array}{l}\text { B:GLU46 } \\
\text { 5:H - } \\
\text { B:SER462 } \\
\text { :O }\end{array}$ & 2.43899 & $\begin{array}{l}\text { Hydrogen } \\
\text { Bond }\end{array}$ & $\begin{array}{l}\text { Conventio } \\
\text { nal } \\
\text { Hydrogen } \\
\text { Bond }\end{array}$ & H-Donor & H-Acceptor \\
\hline & & $\begin{array}{l}\text { B:ARG46 } \\
\text { 9:H - } \\
\text { B:GLU46 } \\
\text { 5:O }\end{array}$ & 1.95876 & $\begin{array}{l}\text { Hydrogen } \\
\text { Bond }\end{array}$ & $\begin{array}{l}\text { Conventio } \\
\text { nal } \\
\text { Hydrogen } \\
\text { Bond }\end{array}$ & H-Donor & H-Acceptor \\
\hline & & $\begin{array}{l}\text { B:ARG15 } \\
\text { 0:HH12 - } \\
\text { B:LEU15 } \\
\text { 2:O }\end{array}$ & 2.27971 & $\begin{array}{l}\text { Hydrogen } \\
\text { Bond }\end{array}$ & $\begin{array}{l}\text { Conventio } \\
\text { nal } \\
\text { Hydrogen } \\
\text { Bond }\end{array}$ & H-Donor & H-Acceptor \\
\hline & & $\begin{array}{l}\text { A:ALA15 } \\
6- \\
\text { A:CYS37 }\end{array}$ & 4.29864 & $\begin{array}{l}\text { Hydrophobi } \\
\text { c }\end{array}$ & Alkyl & Alkyl & Alkyl \\
\hline
\end{tabular}


Jurnal Mangifera Edu, Volume 6, Issue 2, January 2022, 115-128

\section{Interaksi Molekuler Senyawa Homocapsaicin Terhadap COX-2}

Interaksi molekuler senyawa homocapsaicin dengan COX-2 merilis ikatan residu asam amino LEU238 bersifat alkyl. Residu asam amino ASP229 bersifat Pi-Arson. Residu asam amino GLN241 membentuk unfavorable bump. Residu asam amino TRP139, LYS333, dan GLY235 membentuk unfavorable acceptor. Dan residu asam amino GLU140, ASN144, LEU145, PHE142, SER143, ASN231, GLN330, GLU236, ARG222, PHE329, TYR234, ASP239, THR237, LEU230, GLY225, GLY223, dan LYS211 membentuk gaya van der waals (Gambar 3. b). Homocapsaicin dan COX-2 menunjukkan interaksi pengikatan amino residu asam dengan menghasilkan energi sebesar $-279.83 \mathrm{cal} / \mathrm{mol}$.

a.

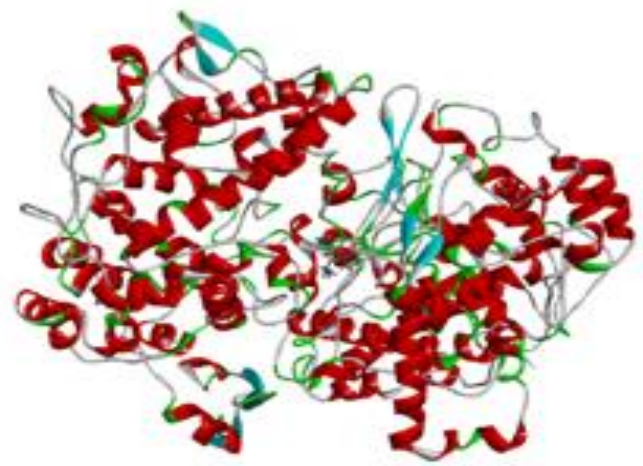

b.

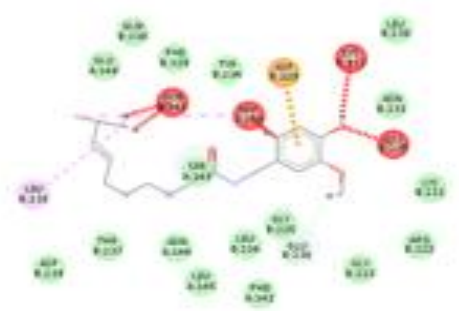

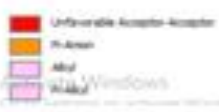

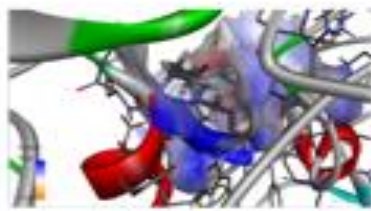

4.
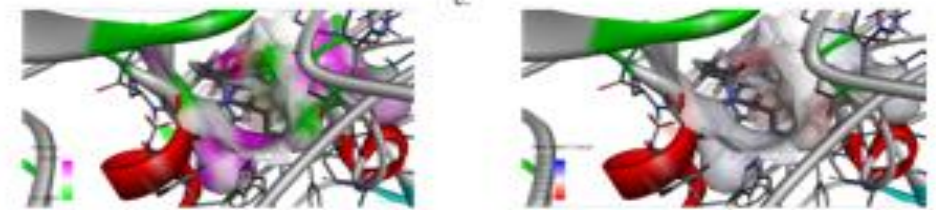

f.
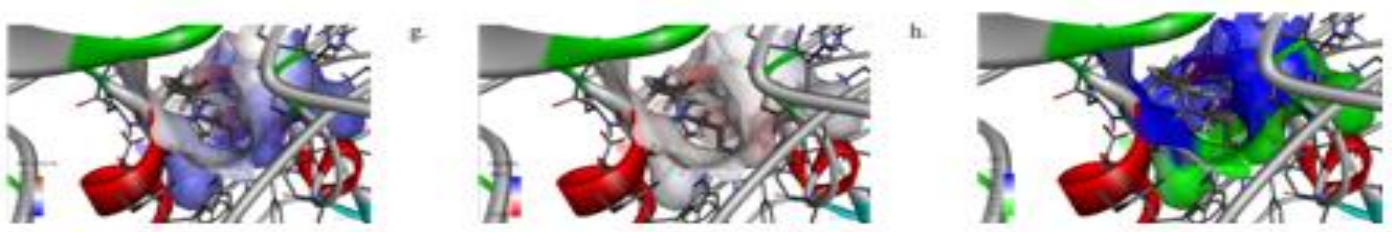

Gambar 3. Interaksi Senyawa Homocapsaicin dan COX-2 a. Struktur 3D, b. Struktur 2D, c. Aromatic, d. H-Bond, e. Charge, f. Hydrophobic, g. Ionizability, h. SAS)

Interaksi antara COX-2 dengan homocapsaicin menunjukkan nilai aromatic pada senyawa homocapsaicin (Gambar 3c). Senyawa homocapsaicin juga berfungsi sebagai donor dan acceptor terhadap COX-2 (Gambar 3d). Senyawa homocapsaicin cenderung bersifat netral sehingga ligan bermuatan 0 (Gambar 3e dan Gambar 3g). Interaksi antara COX-2 dengan homocapsaicin menunjukkan tingkat hidrofobisitas yang rendah (Gambar 3f). Nilai Solvent Accessible Surfance (SAS) pada permukaan homocapsaicin cukup tinggi (Gambar 3h). Tampilan interaksi ini memberikan informasi bahwa ikatan antar ligan dan 
Jurnal Mangifera Edu, Volume 6, Issue 2, January 2022, 115-128

protein memiliki nilai interaksi yang sangat tinggi terhadap pengikatan sisi aktif dari protein COX-2 (Bare dkk., 2019; Santoso \& Atmajaya, 2016).

Tabel 4. Interaksi Senyawa Homocapsaicin dan COX-2

\begin{tabular}{|c|c|c|c|c|c|c|c|}
\hline Complexes & $\begin{array}{c}\text { Energy } \\
\text { (Kal/ } \\
\text { Mol) }\end{array}$ & Name & Distance & Category & Types & $\begin{array}{c}\text { From } \\
\text { Chemistry }\end{array}$ & $\begin{array}{c}\text { From } \\
\text { Chemistry }\end{array}$ \\
\hline \multirow[t]{13}{*}{$\begin{array}{l}\text { Homocapsai } \\
\text { cin- COX2 }\end{array}$} & -279.83 & $\begin{array}{l}\text { A:GLU140:H - } \\
\text { B:GLN330:OE } \\
1\end{array}$ & 2.5992 & $\begin{array}{l}\text { Hydrogen } \\
\text { Bond }\end{array}$ & $\begin{array}{l}\text { Conventi } \\
\text { onal } \\
\text { Hydroge } \\
\text { n Bond }\end{array}$ & H-Donor & $\begin{array}{l}\mathrm{H}- \\
\text { Acceptor }\end{array}$ \\
\hline & & $\begin{array}{l}\text { A:ASN144:H - } \\
\text { A:GLU140:O }\end{array}$ & 2.01938 & $\begin{array}{l}\text { Hydrogen } \\
\text { Bond }\end{array}$ & $\begin{array}{l}\text { Conventi } \\
\text { onal } \\
\text { Hydroge } \\
\text { n Bond }\end{array}$ & H-Donor & $\begin{array}{l}\mathrm{H}- \\
\text { Acceptor }\end{array}$ \\
\hline & & $\begin{array}{l}\text { A:PHE142:H - } \\
\text { A:TRP139:O }\end{array}$ & 2.38635 & $\begin{array}{l}\text { Hydrogen } \\
\text { Bond }\end{array}$ & $\begin{array}{l}\text { Conventi } \\
\text { onal } \\
\text { Hydroge } \\
\text { n Bond }\end{array}$ & H-Donor & $\begin{array}{l}\text { H- } \\
\text { Acceptor }\end{array}$ \\
\hline & & $\begin{array}{l}\text { A:LEU145:H - } \\
\text { A:SER143:O }\end{array}$ & 2.84573 & $\begin{array}{l}\text { Hydrogen } \\
\text { Bond }\end{array}$ & $\begin{array}{l}\text { Conventi } \\
\text { onal } \\
\text { Hydroge } \\
\text { n Bond }\end{array}$ & H-Donor & $\begin{array}{l}\text { H- } \\
\text { Acceptor }\end{array}$ \\
\hline & & $\begin{array}{l}\text { A:SER143:H - } \\
\text { A:TRP139:O }\end{array}$ & 1.63661 & $\begin{array}{l}\text { Hydrogen } \\
\text { Bond }\end{array}$ & $\begin{array}{l}\text { Conventi } \\
\text { onal } \\
\text { Hydroge } \\
\text { n Bond }\end{array}$ & H-Donor & $\begin{array}{l}\mathrm{H}- \\
\text { Acceptor }\end{array}$ \\
\hline & & $\begin{array}{l}\text { B:ARG222:H - } \\
\text { B:LYS211:O }\end{array}$ & 2.81758 & $\begin{array}{l}\text { Hydrogen } \\
\text { Bond }\end{array}$ & $\begin{array}{l}\text { Conventi } \\
\text { onal } \\
\text { Hydroge } \\
\text { n Bond }\end{array}$ & H-Donor & $\begin{array}{l}\mathrm{H}- \\
\text { Acceptor }\end{array}$ \\
\hline & & $\begin{array}{l}\text { B:LYS211:H - } \\
\text { B:TYR148:OH }\end{array}$ & 2.1087 & $\begin{array}{l}\text { Hydrogen } \\
\text { Bond }\end{array}$ & $\begin{array}{l}\text { Conventi } \\
\text { onal } \\
\text { Hydroge } \\
n \text { Bond }\end{array}$ & H-Donor & $\begin{array}{l}\mathrm{H}- \\
\text { Acceptor }\end{array}$ \\
\hline & & $\begin{array}{l}\text { B:GLY223:H - } \\
\text { B:THR221:OG } \\
1\end{array}$ & 1.98063 & $\begin{array}{l}\text { Hydrogen } \\
\text { Bond }\end{array}$ & $\begin{array}{l}\text { Conventi } \\
\text { onal } \\
\text { Hydroge } \\
\text { n Bond }\end{array}$ & H-Donor & $\begin{array}{l}\mathrm{H}- \\
\text { Acceptor }\end{array}$ \\
\hline & & $\begin{array}{l}\text { B:GLY225:CA } \\
- \\
\text { B:ASP229:OD2 }\end{array}$ & 3.69079 & $\begin{array}{l}\text { Hydrogen } \\
\text { Bond }\end{array}$ & $\begin{array}{l}\text { Carbon } \\
\text { Hydroge } \\
\text { n Bond }\end{array}$ & H-Donor & $\begin{array}{l}\text { H- } \\
\text { Acceptor }\end{array}$ \\
\hline & & $\begin{array}{l}\text { B:LEU230:H - } \\
\text { B:GLN208:OE } \\
1\end{array}$ & 2.75095 & $\begin{array}{l}\text { Hydrogen } \\
\text { Bond }\end{array}$ & $\begin{array}{l}\text { Conventi } \\
\text { onal } \\
\text { Hydroge } \\
\text { n Bond }\end{array}$ & H-Donor & $\begin{array}{l}\text { H- } \\
\text { Acceptor }\end{array}$ \\
\hline & & $\begin{array}{l}\text { B:ASN231:H - } \\
\text { B:ASP229:OD1 }\end{array}$ & 1.85615 & $\begin{array}{l}\text { Hydrogen } \\
\text { Bond }\end{array}$ & $\begin{array}{l}\text { Conventi } \\
\text { onal } \\
\text { Hydroge } \\
\text { n Bond }\end{array}$ & H-Donor & $\begin{array}{l}\text { H- } \\
\text { Acceptor }\end{array}$ \\
\hline & & $\begin{array}{l}\text { B:TYR234:H - } \\
\text { B:LEU230:O }\end{array}$ & 1.89907 & $\begin{array}{l}\text { Hydrogen } \\
\text { Bond }\end{array}$ & $\begin{array}{l}\text { Conventi } \\
\text { onal } \\
\text { Hydroge } \\
\text { n Bond }\end{array}$ & H-Donor & $\begin{array}{l}\text { H- } \\
\text { Acceptor }\end{array}$ \\
\hline & & $\begin{array}{l}\text { B:ARG240:H - } \\
\text { B:THR237:O }\end{array}$ & 2.73427 & $\begin{array}{l}\text { Hydrogen } \\
\text { Bond }\end{array}$ & $\begin{array}{l}\text { Conventi } \\
\text { onal } \\
\text { Hydroge } \\
\text { n Bond }\end{array}$ & H-Donor & $\begin{array}{l}\text { H- } \\
\text { Acceptor }\end{array}$ \\
\hline
\end{tabular}


Jurnal Mangifera Edu, Volume 6, Issue 2, January 2022, 115-128

\begin{tabular}{|c|c|c|c|c|c|c|c|}
\hline Complexes & $\begin{array}{c}\text { Energy } \\
\text { (Kal/ } \\
\text { Mol) }\end{array}$ & Name & Distance & Category & Types & $\begin{array}{c}\text { From } \\
\text { Chemistry }\end{array}$ & $\begin{array}{c}\text { From } \\
\text { Chemistry }\end{array}$ \\
\hline & & $\begin{array}{l}\text { B:GLU236:H - } \\
\text { B:GLU236:OE } \\
1\end{array}$ & 2.00782 & $\begin{array}{l}\text { Hydrogen } \\
\text { Bond }\end{array}$ & $\begin{array}{l}\text { Conventi } \\
\text { onal } \\
\text { Hydroge } \\
\text { n Bond }\end{array}$ & H-Donor & $\begin{array}{l}\text { H- } \\
\text { Acceptor }\end{array}$ \\
\hline & & $\begin{array}{l}\text { B:HIS242:H - } \\
\text { B:ASP239:O }\end{array}$ & 2.54195 & $\begin{array}{l}\text { Hydrogen } \\
\text { Bond }\end{array}$ & $\begin{array}{l}\text { Conventi } \\
\text { onal } \\
\text { Hydroge } \\
\text { n Bond }\end{array}$ & H-Donor & $\begin{array}{l}\text { H- } \\
\text { Acceptor }\end{array}$ \\
\hline & & $\begin{array}{l}\text { B:PHE329:H - } \\
\text { B:ASP325:O }\end{array}$ & 1.90825 & $\begin{array}{l}\text { Hydrogen } \\
\text { Bond }\end{array}$ & $\begin{array}{l}\text { Conventi } \\
\text { onal } \\
\text { Hydroge } \\
\text { n Bond }\end{array}$ & H-Donor & $\begin{array}{l}\text { H- } \\
\text { Acceptor }\end{array}$ \\
\hline & & $\begin{array}{l}\text { B:GLN330:H - } \\
\text { B:GLU326:O }\end{array}$ & 1.95422 & $\begin{array}{l}\text { Hydrogen } \\
\text { Bond }\end{array}$ & $\begin{array}{l}\text { Conventi } \\
\text { onal } \\
\text { Hydroge } \\
\text { n Bond }\end{array}$ & H-Donor & $\begin{array}{l}\text { H- } \\
\text { Acceptor }\end{array}$ \\
\hline & & $\begin{array}{l}\text { B:GLN241:H - } \\
\text { B:THR237:O }\end{array}$ & 1.80191 & $\begin{array}{l}\text { Hydrogen } \\
\text { Bond }\end{array}$ & $\begin{array}{l}\text { Conventi } \\
\text { onal } \\
\text { Hydroge } \\
\text { n Bond }\end{array}$ & H-Donor & $\begin{array}{l}\text { H- } \\
\text { Acceptor }\end{array}$ \\
\hline & & $\begin{array}{l}\text { B:GLY235:H - } \\
\text { B:ASN231:O }\end{array}$ & 1.89559 & $\begin{array}{l}\text { Hydrogen } \\
\text { Bond }\end{array}$ & $\begin{array}{l}\text { Conventi } \\
\text { onal } \\
\text { Hydroge } \\
\text { n Bond }\end{array}$ & H-Donor & $\begin{array}{l}\text { H- } \\
\text { Acceptor }\end{array}$ \\
\hline & & $\begin{array}{l}\text { B:ASN231:HD } \\
21 \text { - } \\
\text { B:ASP229:OD1 }\end{array}$ & 2.11814 & $\begin{array}{l}\text { Hydrogen } \\
\text { Bond }\end{array}$ & $\begin{array}{l}\text { Conventi } \\
\text { onal } \\
\text { Hydroge } \\
\text { n Bond }\end{array}$ & H-Donor & $\begin{array}{l}\text { H- } \\
\text { Acceptor }\end{array}$ \\
\hline & & $\begin{array}{l}\text { B:LYS333:H - } \\
\text { B:PHE329:O }\end{array}$ & 2.0067 & $\begin{array}{l}\text { Hydrogen } \\
\text { Bond }\end{array}$ & $\begin{array}{l}\text { Conventi } \\
\text { onal } \\
\text { Hydroge } \\
\text { n Bond }\end{array}$ & H-Donor & $\begin{array}{l}\mathrm{H}- \\
\text { Acceptor }\end{array}$ \\
\hline
\end{tabular}

Pada Tabel 4. terdapat residu asam amino LEU238 membentuk ikatan elektrostatik. Ikatan elektrostatik, adalah ikatan yang jauh lebih umum dari pada ikatan kovalen dalam interaksi reseptor obat. Energi afinitas yang terbentuk $-279.83 \mathrm{cal} / \mathrm{mol}$. Homocapsaicin berpotensi sebagai inhibitor COX-2 dengan menstimulus penghambatan pada lima residu asam amino COX-2. Afinitas yang semakin rendah berdampak terhadap ikatan kekuatan protein dan ligan yang memiliki fungsi sebagai penguat dan penstabil kompleks ligandprotein. Hidrofobisitas yang semakin rendah akan berbanding terbalik terhadap jumlah ikatan hidrofobisitas dan memberikan peningkatan permeabilitas suatu senyawa dalam membran sel (S et al., 2020; Sari et al., 2019). Pengurangan reaksi inflamasi dalam tubuh dilakukan dengan cara menghambat COX-2 oleh senyawa dalam cabai merah keriting sebagai mediator inflamasi yang berperan selama proses inflamasi. Aktivasi COX-2 akan menstimulus prostaglandin G2 menjadi prostaglandin $\mathrm{H} 2$ yang dapat meningkatkan inflamasi dalam tubuh (Kellogg, Pop-Busui, et al., 2008). 
Jurnal Mangifera Edu, Volume 6, Issue 2, January 2022, 115-128

\section{SIMPULAN}

Senyawa cabai memiliki potensi dengan sifat fisikokimia yang baik pada tingkat penyerapan dan permeabilitas terhadap membran sel. Hasil Interaksi molekuler antara senyawa capsacin dengan COX-2 menghasilkan lima residu asam amino, senyawa dihydrocapsaicin terhadap COX-2 tiga residu asam amio sedangkan senyawa homocapsaicin merilis tujuh residu asam amino. Setiap senyawa memiliki karakteristik yang berbeda akan tetapi memiliki kesamaan potensis ebagai anti inflasmi COX-2.

\section{DAFTAR PUSTAKA}

Abdulkhaleq, L. A., Assi, M. A., Abdullah, R., Zamri-Saad, M., Taufiq-Yap, Y. H., \& Hezmee, M. N. M. (2018). The crucial roles of inflammatory mediators in inflammation: A review. Veterinary World, 11(5), 627-635.

Agarwal, P., Das, C., Dias, O., \& Shanbhag, T. (2017). Antimicrobial property of Capsaicin. International Research Journal of Biological Sciences, 6(7), 7-11.

Arumingtyas, E. L., Kusnadi, J., Mastuti, R., \& Faradise, N. S. (2018). The effect of ethyl methane sulfonate on the antioxidant content of chili pepper (Capsicum frutescens L.). AIP Conference Proceedings, 2019. https://doi.org/10.1063/1.5061846

Arumingtyas, E. L., Kusnadi, J., Sari, D. R. T., \& Ratih, N. (2017). Genetic variability of Indonesian local chili pepper: The facts. AIP Conference Proceedings, 1908. https://doi.org/10.1063/1.5012726

Bare, Y. (2021). Analisis Senyawa Fitosterol Cymbopogon citratus dan Curcuma Longa Sebagai Antialzheimer. Biopendix: Jurnal Biologi, Pendidikan dan terapan, 7(2), 53-159. https://doi.org/10.30598/biopendixvol7issue2page153-159

Bare, Y., Marhendra, A., Sasase, T., \& Fatchiyah, F. (2018). Differential Expression of IL10 Gene and Protein in Target Tissues of Rattus Norvegicus Strain Wistar Model Type 2 Diabetes Mellitus (T2DM). Acta Informatica Medica, 26(2), 87-92. https://doi.org/10.5455/aim.2018.26.87-92

Bare, Y., \& Sari, D. R. T. (2021). Pengembangan Lembar Kerja Mahasiswa (LKM) Berbasis Inkuiri Pada Materi Interaksi Molekuler. BioEdUIN, 11(1), 8. https://doi.org/10.15575/bioeduin.v11i1.12077

Bare, Y., Sari, D. R. T., Rachmad, Y. T., Krisnamurti, G. C., \& Elizabeth, A. (2019). In Silico Insight the Prediction of Chlorogenic Acid in Coffee through Cyclooxygenase2 (COX2) Interaction. Biogenesis: Jurnal Ilmiah Biologi, 7(2), 100-105. https://doi.org/10.24252/bio.v7i2.9847

Bayala, B., Coulibaly, A. Y., Djigma, F. W., Nagalo, B. M., Baron, S., Figueredo, G., Lobaccaro, J.-M. A., \& Simpore, J. (2020). Chemical composition, antioxidant, antiinflammatory and antiproliferative activities of the essential oil of Cymbopogon 
Jurnal Mangifera Edu, Volume 6, Issue 2, January 2022, 115-128

nardus, a plant used in traditional medicine. Biomolecular Concepts, 11(1), 86-96. https://doi.org/10.1515/bmc-2020-0007

Bhadoriya, S. S. (2012). Anti-Inflammatory and Antinociceptive Activities of a Hydroethanolic Extract of Tamarindus indica Leaves. Scientia Pharmaceutica, 80(3), 685-700. https://doi.org/10.3797/scipharm.1110-09

Chen, D., Oezguen, N., Urvil, P., Ferguson, C., Dann, S. M., \& Savidge, T. C. (2016). Regulation of protein-ligand binding affinity by hydrogen bond pairing. Science Advances, 2(3). https://doi.org/10.1126/sciadv.1501240

Dima, Cristian; Coman, Gigi; Cotarlet, Mihaela; Alexe, P. and, \& Dima, S. (2013). Antioxidant and Antibacterial Properties of Capsaicine Microemulsions. The Annals of the University Dunarea de Jos of Galati Fascicle VI - Food Technology, 37(1), 39-49. https://doi.org/10.5530/pj.2011.22.11

Fitriani, L., Toekidjo, \& Purwanti, S. (2013). Keragaman Lima Kultivar Cabai (Capsicum annum L.) Di Dataran Medium. Vegetalika, 2(2), 50-63.

Funk, J. L., Frye, J. B., Oyarzo, J. N., Chen, J., Zhang, H., \& Timmermann, B. N. (2016). Anti-inflammatory effects of the essential oils of ginger (Zingiber officinale Roscoe) in experimental rheumatoid arthritis. PharmaNutrition, 4(3), 123-131. https://doi.org/10.1016/j.phanu.2016.02.004

Izzati, F. (2018). Capsaicinoids dari Capsicum spp. Dan Penggunaannya Sebagai Riot Control Agent. BioTrends, 9(2), 9.

Jolayemi, A. T., \& Ojewole, J. A. O. (2013). Comparative anti-inflammatory properties of Capsaicin and ethyl-aAcetate extract of Capsicum frutescens linn [Solanaceae] in rats. African Health Sciences, 13(2), 357-361. https://doi.org/10.4314/ahs.v13i2.23

Kellogg, A., Cheng, H., \& Pop-Busui, R. (2008). Cyclooxygenase-2 Pathway as a Potential Therapeutic Target in Diabetic Peripheral Neuropathy. Current Drug Targets, 9(1), 68-76. https://doi.org/10.2174/138945008783431691

Kellogg, A., Pop-Busui, R., \& Cheng, H. T. (2008). Cyclooxygenase-2 Pathway as a Potential Therapeutic Target in Diabetic Peripheral Neuropathy. Current Drug Targets, 9(1), 68-76. https://doi.org/10.2174/138945008783431691

Kusnadi, J., Wuri Andayani, D., \& Zubaidah, E. (2019). Ekstraksi Senyawa Bioaktif Cabai Rawit (Capsicum Frutescens L.) Menggunakan Metode Ekstraksi Gelombang Ultrasonik. Jurnal Teknologi Pertanian, 20(2), 79-84. https://doi.org/10.21776/ub.jtp.2019.020.02.1

Lipinski, C. A. (2004). Lead- and drug-like compounds: The rule-of-five revolution. Drug Discovery Today: Technologies, $1(4), \quad 337-341$. https://doi.org/10.1016/j.ddtec.2004.11.007

Lipinski, C. A., Lombardo, F., Dominy, B. W., \& Feeney, P. J. (2001). Experimental and computational approaches to estimate solubility and permeability in drug discovery 
Jurnal Mangifera Edu, Volume 6, Issue 2, January 2022, 115-128

and development settingsq. Advanced Drug Delivery Reviews, 24. https://doi.org/10.1016/S0169-409X(00)00129-0

Marini, E., Magi, G., Mingoia, M., Pugnaloni, A., \& Facinelli, B. (2015). Antimicrobial and anti-virulence activity of capsaicin against erythromycin-resistant, cell-invasive group A streptococci. Frontiers in Microbiology, 6, 1-7. https://doi.org/10.3389/fmicb.2015.01281

Musfiroh, I. D. A., Mutakin, M., Angelina, T., \& Muchtaridi, M. (2013). Capsaicin level of various Capsicum fruits. International Journal of Pharmacy and Pharmaceutical Sciences, 5(1), 248-251.

Phan, M. A. T., Paterson, J., Bucknall, M., \& Arcot, J. (2018). Interactions between phytochemicals from fruits and vegetables: Effects on bioactivities and bioavailability. Critical Reviews in Food Science and Nutrition, 58(8), 1310-1329. https://doi.org/10.1080/10408398.2016.1254595

Purwanto, E. (2017). Efektivitas Ekstrak Cabai Rawit (Capsicum frutescens L.) Terhadap Penyembuhan Luka Insisi Pada Mencit (Mus musculus). Universitas Airlangga.

S, M., Bare, Y., Helvina, M., Pili, A. P., \& Krisnamurti, G. C. (2020). Studi In silico Potensi aktivitas 10-shogaol dalam Jahe (Zingiber officinale) terhadap gen ACE. Spizaetus: Jurnal Biologi Dan Pendidikan Biologi, 1(3), 12-18.

Santoso, B., \& Atmajaya, T. E. (2016). Kajian Docking Senyawa 4-[(Z)-N-(4hidroksifenil)carboksimidoil]-2- metoksifenol SEBAGAI INHIBITOR COX-2 Menggunakan Plants. Conference: Prosiding Seminar Nasional Kimia UNJANI-HKI 2016, 9 .

Sari, D. R. T., Cairns, J. R. K., Safitri, A., \& Fatchiyah, F. (2019). Virtual prediction of the delphinidin-3-o-glucoside and peonidin-3-o-glucoside as anti-inflammatory of TNF$\alpha$ signaling. Acta Informatica Medica, 27(3), 152-157. https://doi.org/10.5455/aim.2019.27.152-157

Sukmawati, D. (2015). Pembentukan Harga Cabai Merah Keriting (Capsicum annum L) dengan Analisis Harga Komoditas Di Sentra Produksi Dan Pasar Induk (Suatu Kasus pada Sentra produksi Cabai Merah Keriting di Kecamatan Cikajang, Pasar Induk Gedebage, Pasar Induk Caringin dan Pasar Induk Kramat Jati). Mimbar Agribisnis: Jurnal Pemikiran Masyarakat Ilmiah Berwawasan Agribisnis, 1(1), 79-84. http://dx.doi.org/10.25157/ma.v1i1.35 